\title{
Article \\ Drought Effects on Morpho-Physiological and Biochemical Traits in Persian Oak and Black Poplar Seedlings
}

\author{
Amir Karimi ${ }^{1} \mathbb{D}$, Masoud Tabari ${ }^{1, *} \mathbb{D}$, Zeinab Javanmard ${ }^{1}$ and Martin Karl-Friedrich Bader ${ }^{2, * \mathbb{D}}$ \\ 1 Department of Forest Sciences and Engineering, Faculty of Natural Resources and Marine Sciences, \\ Tarbiat Modares University, Tehran 14117-13116, Iran; amirkarimi.tmu@gmail.com (A.K.); \\ javanmardzeinab0@gmail.com (Z.J.) \\ 2 Department of Forestry and Wood Technology, Linnaeus University, P G Vejdes väg, 35195 Växjö, Sweden \\ * Correspondence: mtabari@modares.ac.ir (M.T.); martin.bader@lnu.se (M.K.-F.B.)
}

check for updates

Citation: Karimi, A.; Tabari, M.; Javanmard, Z.; Bader, M.K.-F. Drought Effects on Morpho-Physiological and Biochemical Traits in Persian Oak and Black Poplar Seedlings. Forests 2022, 13, 399. https://doi.org/ 10.3390/f13030399

Academic Editor: Jesús Julio Camarero

Received: 30 December 2021 Accepted: 24 February 2022 Published: 28 February 2022

Publisher's Note: MDPI stays neutral with regard to jurisdictional claims in published maps and institutional affiliations.

Copyright: (C) 2022 by the authors. Licensee MDPI, Basel, Switzerland. This article is an open access article distributed under the terms and conditions of the Creative Commons Attribution (CC BY) license (https:// creativecommons.org/licenses/by/ $4.0 /)$.

\begin{abstract}
In many arid and semi-arid regions, increasing water scarcity pushes woody species to their physiological limits, making strong drought resistance essential for adaptive forest management. Here, we examined morpho-physiological and biochemical drought responses of the forestry-relevant Persian oak (Quercus brantii Lindl.) and black poplar (Populus nigra L.). In a 120-day greenhouse pot experiment, seedlings were subjected to three watering regimes (FC100, FC60, and FC30, indicating percentages of field capacity). Under FC100 conditions, all biomass measures and the total and specific leaf area of oak were significantly greater compared to those of poplar. FC60-exposed poplar seedlings exhibited strong declines in relative water content (RWC; $-33 \%$ ) and carotenoids $(-46 \%)$ and a surge in electrolyte leakage $(\mathrm{EL} ;+51 \%)$, while these parameters did not change significantly in oak. Although both species showed 80\% EL under FC30 conditions, poplar suffered more severe drought damage than oak as evidenced by a $65 \%$ lower survival, stronger reductions in RWC and total chlorophyll, as well as stronger increases in oxidative stress markers. Accordingly, poplar seedlings displayed a drought-related 56\% decline in quality index while only statistically insignificant reductions occurred in oak seedlings. The superior drought resistance of oak seedlings implies economically more viable nursery production and better seedling establishment, suggesting a shift towards Persian oak-dominated forestry in its natural range under future climate projections.
\end{abstract}

Keywords: electrolyte leakage; malondialdehyde; proline; relative water content; shoot growth

\section{Introduction}

Seedling establishment is a critical phase in reforestation and afforestation projects as this early tree life stage is often associated with high mortality rates [1]. Among the diverse biotic and abiotic causes of seedling death, drought and soil water availability are becoming increasingly limiting factors in many environments as a result of climate change [2]. This poses great challenges for future forest management planning in terms of tree species selection, the provisioning of high-vigour seedlings, and their survival after outplanting, which is critical to successful forest plantation establishment [3]. These problems are particularly acute in semi-arid regions like large parts of Iran, where climatic changes are likely to shift water availability towards the threshold for tree establishment, which may only allow episodic reforestation or afforestation campaigns in the future [4].

Among the most noticeable impacts of drought stress on trees are reductions in leaf area and impaired stem and root development along with a deterioration in water relations [5-8]. In addition, water deficit is often accompanied by changes in other plant morphological, physiological (e.g., electrolyte leakage), and biochemical properties (oxidative stress markers and osmoregulants) together with the degradation of photosynthetic pigments $[9,10]$. For example, increasing drought intensity in populations of Persian oak (Quercus brantii) [11] and Arizona cypress (Cupressus arizonica Greene) led to strong decreases in growth and total biomass [12]. Fast-growing, water demanding poplar species 
showed strong drought-induced reductions in root and shoot growth, leaf mass and area (Populus cathayana Rehd.; [13]), as well as radial growth (Populus deltoides W.Bartram ex Marshall; [14]). For many tree species in semi-arid and Mediterranean-type ecosystems, relative water content (RWC) is one of the key plant physiological traits that declines drastically under water deficit, as has been reported for Quercus ilex [15], Crataegus azarolus L. and Prunus mahaleb L. [16], Pistacia vera L. [17], and Myrtus communis L. [18]. In addition, reductions in foliar gas-exchange, leaf water potential, and whole-tree water use typically occur during drought and have been reported from narrow-range endemics [7] to widely planted, economically important tree species (e.g., Larix kaempferi (Lamb.) Carr., Prunus sargentii (Rehder) H.Ohba (1992) [19]). Often, water limitation is associated with increases in free radicals, causing oxidative damage to cell membranes followed by an increase in electrolyte leakage, which has previously been shown for numerous woody species around the world including Middle Eastern species such as Quercus brantii, Quercus libani G.Olivier [20], and Pistacia atlantica Desf., 1799 [21]. Consequently, oxidative stress markers such as malondialdehyde, a breakdown product of lipid peroxidation, or osmoregulants such as proline, often rise dramatically under drought conditions (e.g., in Myrtus communis [22], Populus spp. [23], Populus deltoides [14]). Photosynthetic pigments (chlorophylls and carotenoids) also respond sensitively to drought, often suffering degradation [19,22-24]. Although modern forest management options such as the use of beneficial soil microorganisms can reduce detrimental drought effects, tree drought tolerance heavily relies on physiological, biochemical, and molecular adaptations [24,25].

Knowledge about morpho-physiological and biochemical drought responses of tree seedlings is thus crucial for guiding forest management planning starting with the adaptation of sustainable nursery production processes to ensure the delivery of high-vigour plant material. However, to date there is little relevant information on the forestry-important Persian oak (Quercus brantii) and black poplar (Populus nigra) in the Middle Eastern region. Persian oak is native to Iran and widely distributed in the vast forests of the Zagros Mountains in western Iran. Compared to co-occurring oak species in these forests (such as $Q$. infectoria and $Q$. libani), $Q$. brantii is more adaptable to changes in soil nutrient and water availability [26]. Due to its high adaptation potential, seedling production of Persian oak is of great importance for the reforestation of degraded lands, afforestation projects, and the development of urban and suburban green spaces. Black poplar (Populus nigra) is a commercially important timber species of temperate and cool temperate regions of the Northern hemisphere, where it forms riparian forests [27]. It is a fast-growing tree with high water consumption, whose productivity is strongly affected by drought [28]. Black poplar is currently extensively planted on riverbanks in many mountainous areas of Iran, especially in the west [29], resulting in afforestation estimates of nearly 70,000 hectares [30].

The naturally occurring droughts in this arid to semi-arid region are forecasted to become more frequent and intense in the future [31]. Given the prominent role of Persian oak and black poplar in regional forest planning and urban forestry initiatives in the western regions of the country, information on their drought resistance is urgently needed to provide guidance for nursery and forestry managers. In this study, we therefore aimed at investigating morphological, physiological, and biochemical responses of seedlings of these forestry-relevant tree species to drought under controlled greenhouse conditions. We hypothesized that seedlings of the native, locally-adapted Persian oak would be less impacted by drought than those of the water-demanding black poplar. Specifically, we anticipated drought-exposed Persian oak seedlings to (i) show higher survival rates, (ii) sustain less severe growth and biomass losses, and (iii) maintain a more favourable water status and thus less oxidative damage and pigment degradation than drought-treated black poplar seedlings.

\section{Materials and Methods}

Two-year-old uniform potted (5 L pot volume) seedlings of Persian oak and black poplar subjected to three different soil water regimes were studied in the Khorramabad 
Nursery, Lorestan province, western Iran ( $33^{\circ} 26^{\prime \prime} \mathrm{N}, 48^{\circ} 18^{\prime \prime} \mathrm{E}, 1155 \mathrm{~m}$ a.s.l.) (Figure 1$)$. The average annual rainfall in this area is $500 \mathrm{~mm}$ and the average minimum and maximum relative humidity is $25 \%$ and $57 \%$, respectively. The semi-arid climate is characterized by hot summers and relatively cold winters with a dry period of 154 days from June to November.

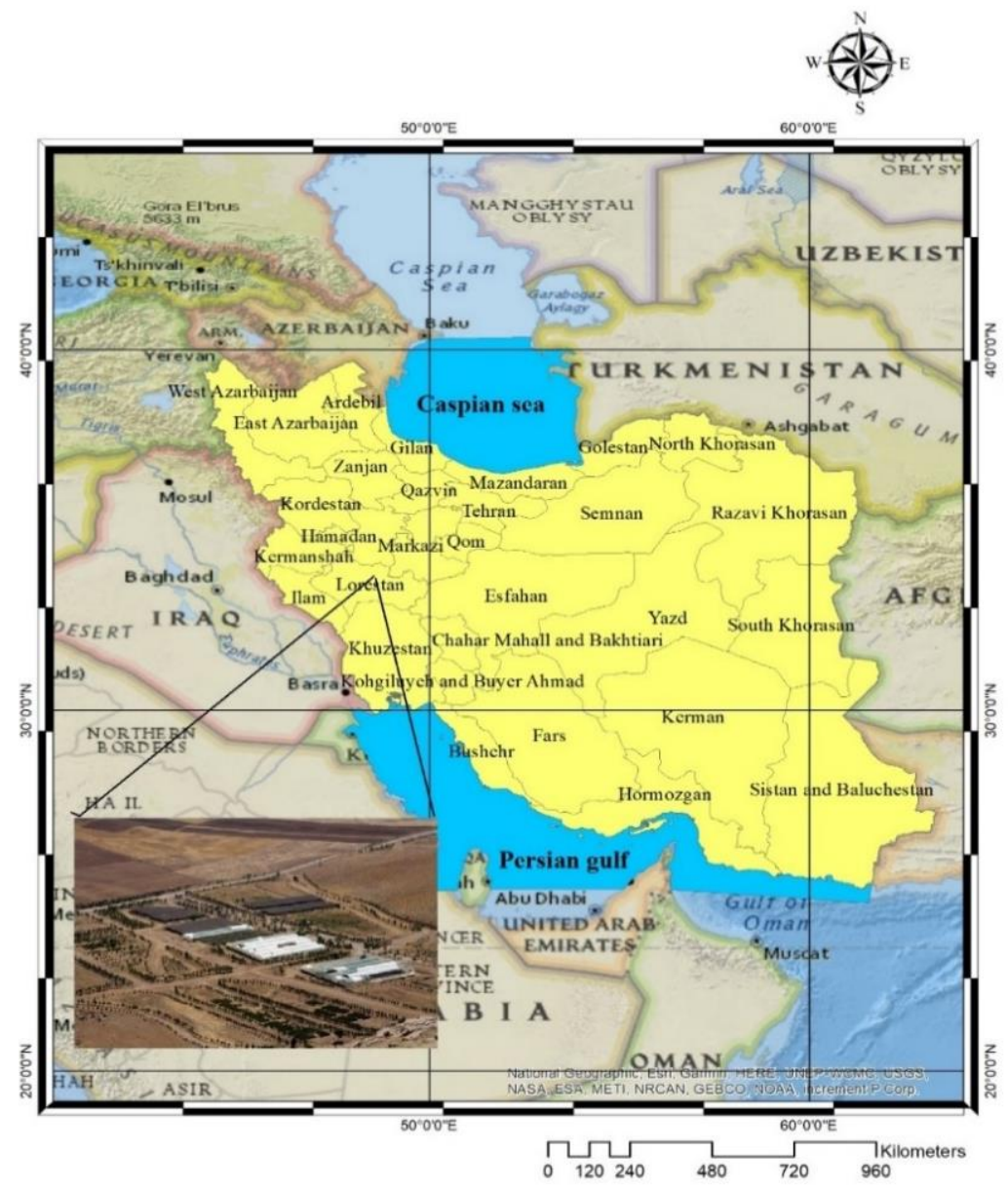

Figure 1. Geographical location of the studied nursery.

The greenhouse experiment was conducted at three levels of soil water deficit (SWD): $100 \%$ (control), $60 \%$, and $30 \%$ field capacity (FC), and was run for 120 days as a randomized complete block design with three replicates (SWD levels are hereafter referred to as FC100, FC60, and FC30). The soil water deficit settings and the irrigation procedure were arranged according to Zarik, L. et al. [32].

\subsection{Survival, Growth and Biomass}

At the end of the experiment, the survival rate was calculated according to Equation (1):

$$
\text { Survival rate }=\frac{\text { Survived seedlings }}{\text { Total seedlings }} \times 100
$$

At the beginning and the end of the experiment, the height and root collar diameter of the seedlings were measured and the growth increase was inferred from the difference between the first and final recordings. From each treatment, three seedlings were randomly selected, and after carefully washing away the soil clinging to the roots, their length was measured with a tape meter. The leaf, root, and stem samples were placed in a drying oven at $70{ }^{\circ} \mathrm{C}$ for $48 \mathrm{~h}$, followed by biomass determination using a digital scale with an accuracy of $0.0001 \mathrm{~g}$. Total seedling biomass was calculated as the sum of root, leaf, and shoots dry weights. The leaf area of six fully developed leaves from the top of each seedling was 
determined using a leaf area meter (Model LI-3000, Li-Cor, Lincoln, NE, USA). Specific leaf area (SLA) was determined by dividing leaf area by leaf dry weight [33].

\subsection{Seedling Quality Index}

The Dickson quality index (DQI) was calculated according to Dickson, A. et al. [34]:

$$
\mathrm{DQI}=\frac{\mathrm{TB}(\mathrm{g})}{\frac{\mathrm{H}(\mathrm{cm})}{\mathrm{D}(\mathrm{mm})}+\frac{\mathrm{SB}(\mathrm{g})}{\mathrm{RB}(\mathrm{g})}}
$$

where $\mathrm{TB}=$ total seedling biomass $(\mathrm{g}), \mathrm{SB}=$ shoot biomass $(\mathrm{g}), \mathrm{RB}=$ root biomass $(\mathrm{g})$, $\mathrm{H}=$ seedling height, and $\mathrm{D}=$ seedling root collar diameter.

\subsection{Relative Water Content}

To assess the relative water content (RWC), three mature leaves of the selected seedlings were sampled and immediately weighed for fresh weight (FW) determination. Then, these samples were placed in distilled water in the dark for $24 \mathrm{~h}$ to allow water absorption and swelling, followed by reweighing to determine turgid weight (TW). The samples were then placed in a drying oven at $70^{\circ} \mathrm{C}$ for $48 \mathrm{~h}$ and weighed again to assess their dry weight (DW). Finally, the RWC was determined according to Equation (3) [35]:

$$
\operatorname{RWC}(\%)=\frac{\mathrm{FW}-\mathrm{DW}}{\mathrm{TW}-\mathrm{DW}} \times 100
$$

\subsection{Electrolyte Leakage}

Electrolyte leakage (EL) was assessed following the protocol by Campos et al. [36]. First, small leaf pieces $\left(0.25 \mathrm{~cm}^{2}\right)$ were prepared from $100 \mathrm{mg}$ of fresh leaf material and introduced into $50 \mathrm{~mL}$ falcon tubes with $15 \mathrm{~mL}$ double distilled water. The tubes were plunged in a boiling water bath at $80^{\circ} \mathrm{C}$ for $12 \mathrm{~h}$. After $2 \mathrm{~h}$, electrical conductivity (EC1) was gauged by an electrical conductivity meter. Then, the samples were maintained in a non-ventilated oven at $120^{\circ} \mathrm{C}$ for $120 \mathrm{~min}$. After the samples had cooled down to $25^{\circ} \mathrm{C}$, final electrical conductivity (EC2) was determined. The EL was derived by the following Equation (4):

$$
\mathrm{EL}(\%)=\frac{\mathrm{EC} 1}{\mathrm{EC} 2} \times 100
$$

\subsection{Plant Pigment Content}

To estimate pigment content, $0.1 \mathrm{~g}$ of frozen leaf discs was extracted at $-80^{\circ} \mathrm{C}$ with $0.1 \mathrm{~g}$ of calcium carbonate and $4 \mathrm{~mL}$ of $80 \%$ acetone in the dark. The liquid part was transferred into another test tube and centrifuged at $4000 \mathrm{rpm}$ for $10 \mathrm{~min}$ at $4{ }^{\circ} \mathrm{C}$. After the collection of the supernatant, the absorbance was spectrophotometrically recorded at 470, 645, and $663 \mathrm{~nm}$ (PG Instruments T60 Spectrophotometer, Wibtoft, Leicestershire, UK). The content of chlorophyll (chl) $a$, chl $b$, and carotenoids were determined using Equations (5)-(7) [37]:

$$
\begin{gathered}
\text { Chl } a \text { concentration }=12.7(\mathrm{~A} 663)-2.69(\mathrm{~A} 645) \times\left(\frac{\mathrm{V}}{\mathrm{W} \times 1000}\right) \\
\text { Chl } b \text { concentration }=22.9(\mathrm{~A} 645)-4.68(\mathrm{~A} 663) \times\left(\frac{\mathrm{V}}{\mathrm{W} \times 1000}\right) \\
\text { Carotenoid concentration }=(\mathrm{A} 470)-14.4(\mathrm{~A} 663)-63.08(\mathrm{~A} 645) \times\left(\frac{\mathrm{V}}{\mathrm{W} \times 1000}\right)
\end{gathered}
$$

where $\mathrm{V}=$ the volume of acetone used $(\mathrm{mL})$ and $\mathrm{W}=$ the weight of the isolated leaf tissue (g). Pigment concentrations are given in $\mathrm{mg} \mathrm{g}^{-1}$ fresh weight (FW). Total chl content was estimated by the sum of $\operatorname{chl} a$ and $\operatorname{chl} b$. 


\subsection{Malondialdehyde (MDA)}

First, $0.2 \mathrm{~g}$ of frozen leaf discs of each species was homogenized in $4 \mathrm{~mL}$ of trichloroacetic acid (TCA) solution buffer and centrifuged at $1500 \mathrm{rpm}$ for $15 \mathrm{~min}$. Then, $2 \mathrm{~mL}$ of the supernatant was collected and $2.5 \mathrm{~mL}$ of $5 \%$ thiobarbituric acid (TBA) solution was added. The mixture was placed in a hot water bath at $95{ }^{\circ} \mathrm{C}$ for $50 \mathrm{~min}$ and then centrifuged at 10,000 rpm for $10 \mathrm{~min}$. After cooling in ice water for $10 \mathrm{~min}$, absorption was read spectrophotometrically at $532 \mathrm{~nm}$ and the concentration of MDA was calculated using the extinction coefficient of $155 \mathrm{~mm}^{-1} \mathrm{~cm}^{-1}$ [38].

\subsection{Proline}

Following the procedure by Bates, L. S. et al. [39], $0.5 \mathrm{~g}$ of frozen leaves of each species (and each treatment level) were extracted with $5 \mathrm{~mL}$ of $3 \%$ sulfosalicylic acid. This extract was centrifuged for $15 \mathrm{~min}$ at $6000 \mathrm{rpm}$ at $4{ }^{\circ} \mathrm{C}$. Then, $2 \mathrm{~mL}$ of the supernatant was mixed with $2 \mathrm{~mL}$ of ninhydrin reagent, $30 \mathrm{~mL}$ of glacial acetic acid, and $2 \mathrm{~mL}$ of acetic acid and placed in a hot water bath at $95^{\circ} \mathrm{C}$ for $1 \mathrm{~h}$. After cooling in ice, $4 \mathrm{~mL}$ of toluene was added to the samples and vortexed for $15 \mathrm{~min}$ after being kept in the dark for $20 \mathrm{~min}$. The absorption of the pink upper phase containing toluene and proline was read by a spectrophotometer at $520 \mathrm{~nm}$ and the amount of proline was calculated using a standard curve based on 50, 40, $30,20,10,5,2.5$, and $0 \mu \mathrm{M}$ pure proline.

\subsection{Data Analysis}

Data analysis was performed using SPSS software ver. 26 (SPSS Inc., Chicago, IL, USA). The normality and homogeneity of the data were determined by Kolmogorov-Smirnov and Levene tests, respectively. Two-way ANOVA was used to determine whether an overall statistically significant treatment effect occurred. Duncan's multiple range test was applied as a post-hoc analysis to compare treatment means. Graphs were drawn with Excel 2016 software.

\section{Results}

\subsection{Survival and Growth}

Seedling survival responded more sensitively to soil water deficit (SWD) in black poplar compared to Persian oak, resulting in a significant drought $\times$ species interaction (Figure 2). Oak losses only occurred in the most severe drought treatment (FC30), causing a moderate reduction in survival down to $83 \%$ (Figure 2). By contrast, black poplar seedlings succumbed more readily to SWD, resulting in $83 \%$ survival under FC60 conditions and merely $29 \%$ survival in the FC30 treatment (Figure 2).

We neither detected a significant drought $\times$ species interaction nor a significant species effect on height growth (Figure 2). However, drought alone had a statistically significant effect, leading to similar height growth reductions of around $50 \%$ in both species under severe SWD (FC30), though FC60 conditions affected oak seedlings less than black poplar plants (Figure 2).

The interaction between SWD and species identity had a significant effect on diameter growth (Figure 2). Under well-watered conditions, black poplar seedlings showed significantly greater diameter growth than oak seedlings but suffered a $41 \%$ growth reduction under FC60 conditions which, however, had no significant effect on oak radial growth (Figure 2). Under FC30 conditions, the diameter increment in both species had roughly halved compared to that in the FC100 conditions (Figure 2). 

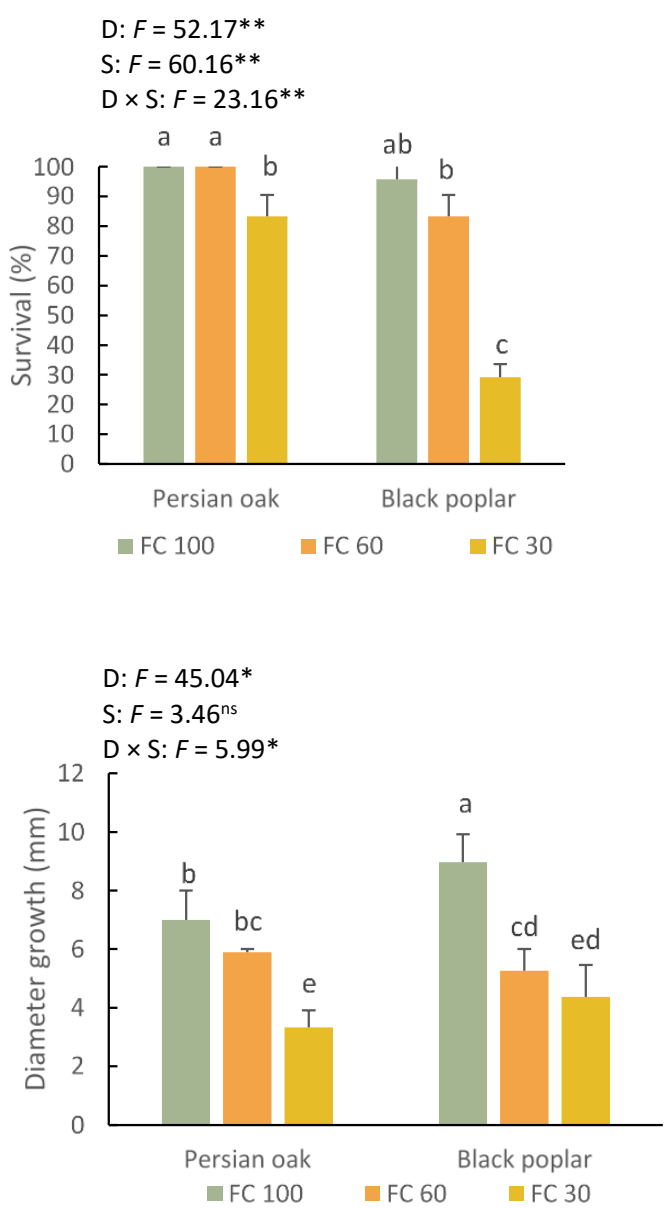

$D: F=44.81^{*}$

S: $F=5.35^{*}$

$D \times S: F=0.69^{\text {ns }}$

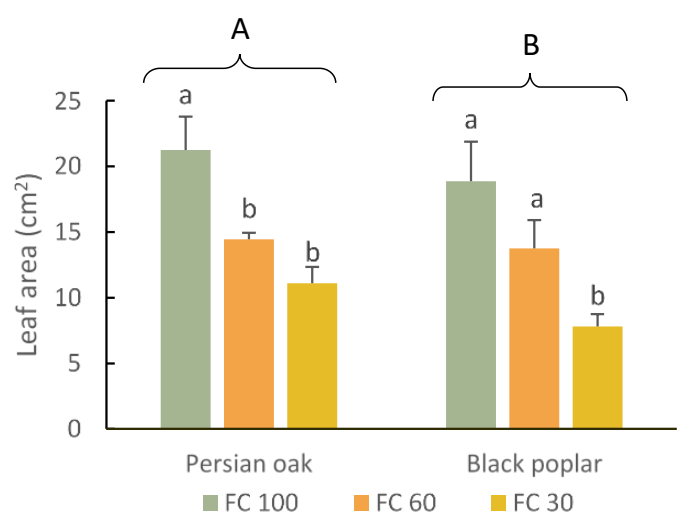

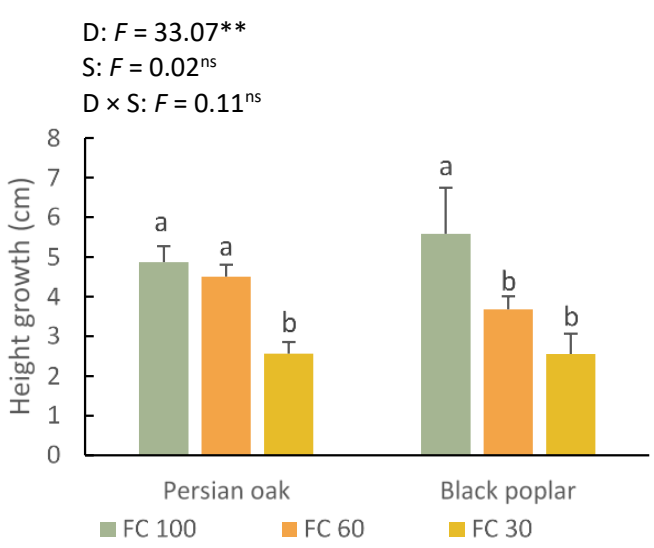

D: $F=8.40^{*}$

S: $F=5.00^{*}$

$\mathrm{D} \times \mathrm{S}: F=39.40^{*}$

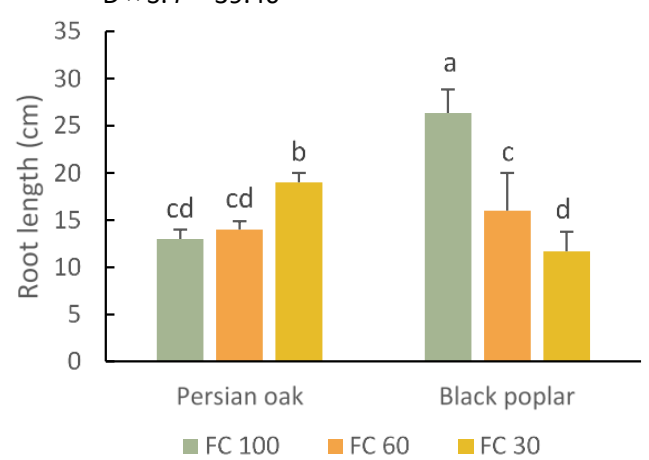

D: $F=2.59^{\text {ns }}$

S: $F=14.86^{*}$

$\mathrm{D} \times \mathrm{S}: F=0.28^{\mathrm{ns}}$

A

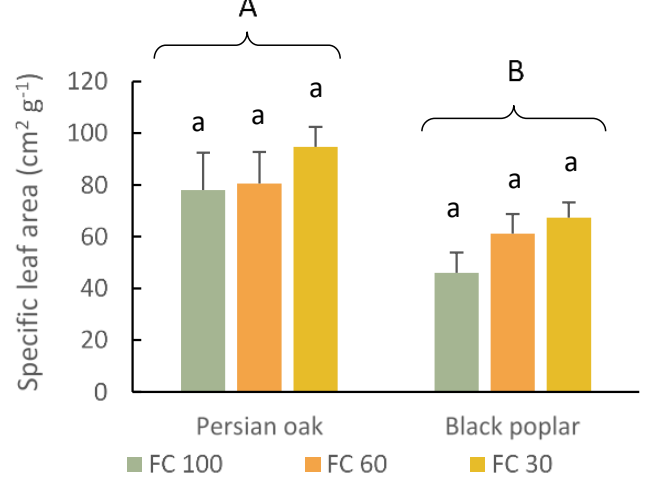

Figure 2. Survival, height and diameter growth, root length, total leaf area, and specific leaf area of Persian oak and black poplar seedlings as a function of soil water deficit. Means \pm standard deviation, $n=3$ blocks. Different lower-case letters indicate statistically significant differences based on Duncan's multiple range post-hoc test $(\alpha=0.05)$. In the presence of a significant interaction between drought (D) and species (S), the significance letters are valid across species but only remain valid within species when the interaction $(\mathrm{D} \times \mathrm{S})$ was not significant. Different upper-case letters indicate statistically significant differences between species in the absence of a significant $\mathrm{D} \times \mathrm{S}$ interaction. ${ }^{*} p<0.05,{ }^{* *} p<0.01$. 
Root length was also significantly affected by the two-way interaction between drought and species identity (Figure 2). Compared to the unstressed control, the root length of oak seedlings remained unchanged under FC60 conditions and increased significantly by $46 \%$ in response to severe SWD (Figure 2). Under FC100 conditions, the roots of black poplar seedlings were two times longer than those of the oaks, but root length declined significantly with increasing SWD (FC60: -39\%, FC30: -56\%; Figure 2). There was no significant drought $\times$ species interaction with regard to total leaf area, but both main effects were significant. In both species, total leaf area decreased with increasing SWD, leading to reductions of $48 \%$ in oak and 59\% in black poplar under severe SWD (Figure 2). Overall, oak seedlings had a slightly but significantly larger total leaf area than black poplar seedlings. Specific leaf area (SLA) was significantly greater in oak compared to black poplar, but there was neither a significant drought $\times$ species interaction nor a significant effect of SWD alone (Figure 2).

\subsection{Biomass and Seedling Quality Index}

In both species, seedling shoot biomass declined with increasing SWD, but black poplar showed greater reductions $(-68 \%)$ than oak $(-38 \%)$ under FC30 conditions compared to the unstressed control plants, resulting in a significant drought $\times$ species interaction (Figure 3). Under well-watered conditions, oak seedlings had a 4.7 times higher root biomass than black poplar seedlings (Figure 3). However, while oak root biomass declined significantly by 25-35\% under FC60 and FC30 conditions, the much lower root mass of black poplar seedlings remained unaffected by SWD, resulting in a significant two-way interaction between drought and species identity (Figure 3). The Dickson quality index (DQI) was not significantly affected by the interaction between drought and species identity, but both main effects were significant (Figure 3). The DQI of oak seedlings was far superior to that of black poplar and did not decline significantly with increasing SWD, averaging 20.7 across treatments. Unstressed black poplar control seedlings showed a DQI of 14.6, which decreased to $9.5(-35 \%)$ in the FC60 treatment and deteriorated to $6.5(-56 \%)$ under FC30 conditions (Figure 3).

\subsection{Photosynthetic Pigments}

In both species, chlorophyll (chl) $a, b$, and total chl as well as carotenoid content diminished significantly with increasing drought intensity, resulting in reductions of around $50 \%$ or more (Figure 4 ). At each treatment level, the two species showed similar pigment contents, except for the significantly higher carotenoid content of oak seedling foliage in the FC60 treatment, which exceeded the values seen in black poplar by $86 \%$ (Figure 4 ).

\subsection{Water Relation and Biochemical Traits}

In both species, RWC decreased significantly with increasing SWD (Figure 5). However, black poplar seedlings already had significantly lower RWC than oak plants under well-watered conditions and showed greater reductions in response to drought stress (Q. brantii FC60: -15\%, FC30: -39\%; P. nigra FC60: -33\%, FC30: -47\%), producing a significant drought $\times$ species interaction (Figure 5). This two-way interaction was also significant with regard to EL, which showed similar levels among species in the absence of drought stress and also a similarly large (more than 1.7-fold) increase in the FC30 treatment. However, under FC60 conditions, EL in oak seedlings only rose by $18 \%$ while black poplar seedlings showed an increase of 51\% relative to the control (Figure 5). Drought treatment and species identity also had a significant interactive effect on foliar proline content (Figure 5). Under FC100 conditions, both species showed similar proline levels. In oak seedlings, the FC60 treatment did not cause significant changes in proline but a 50\% increase occurred under FC30 conditions (Figure 5). By contrast, black poplar seedlings already showed a $62 \%$ increase in proline content under FC60 conditions and a 165\% rise in the FC30 treatment compared to the non-stressed control. A similar pattern characterized by a significant drought $\times$ species interaction was observed for MDA (Figure 5). Malon- 
dialdehyde levels in oak seedling foliage did not rise under moderate SWD but doubled under FC30 conditions compared to the control. In leaves of FC60-treated black poplar seedlings, MDA concentrations increased by $142 \%$ and reached $174 \%$ in the FC30 treatment (Figure 5).
D: $F=93.21$ *
S: $F=111.76$ *
$\mathrm{D} \times \mathrm{S}: F=8.69$ *

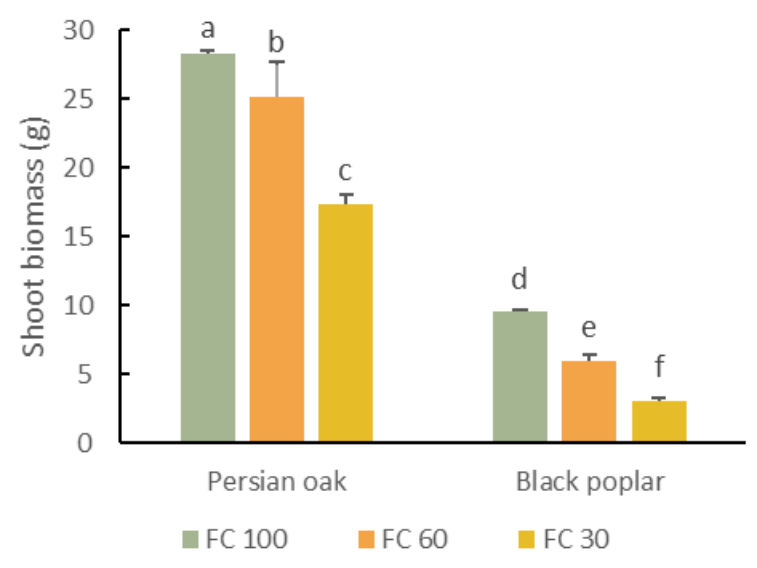

D: $F=6.83 *$

S: $F=169.49$ *

$\mathrm{D} \times \mathrm{S}: F=3.79^{\mathrm{ns}}$

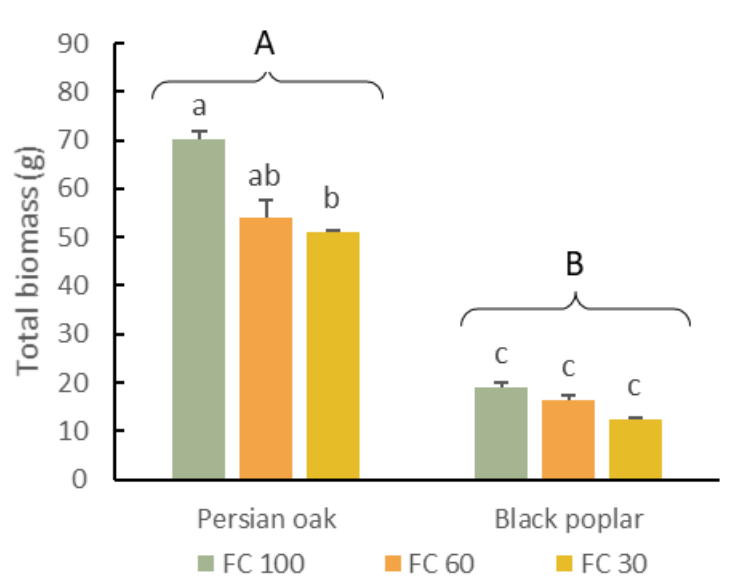
$\mathrm{D}: F=1.55^{\mathrm{n}}$
S: $F=67.27$ *
$\mathrm{D} \times \mathrm{S}: F=4.23 *$

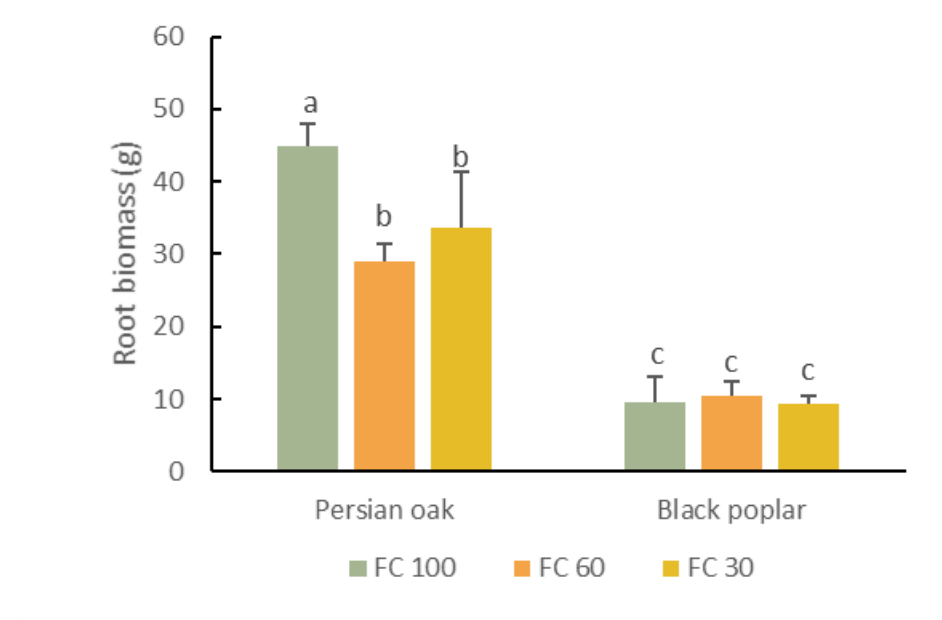

D: $F=5.72$

S: $F=31.59 *$

$\mathrm{D} \times \mathrm{S}: F=0.84^{\mathrm{ns}}$

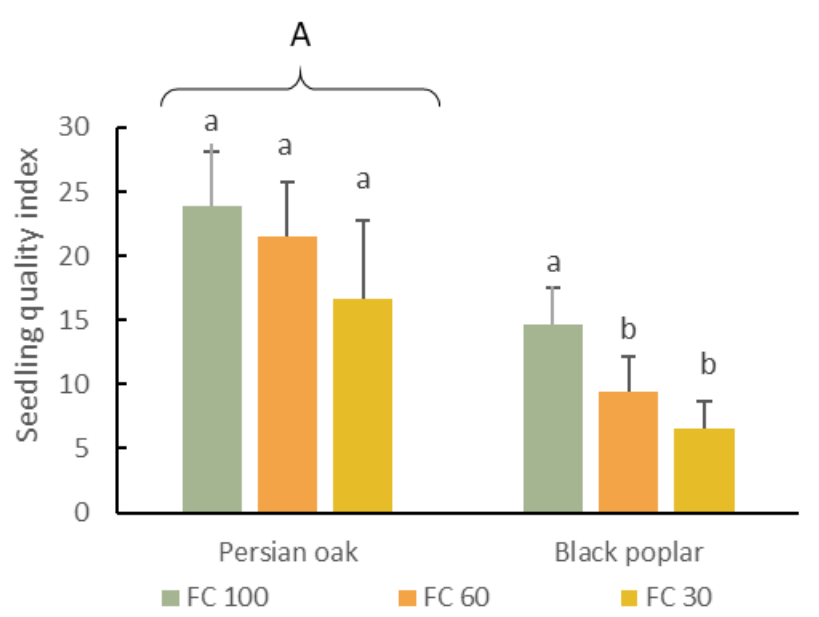

Figure 3. Shoot, root, and total biomass along with the Dickson quality index of Persian oak and black poplar seedlings as a function of soil water deficit. Means \pm standard deviation, $n=3$ blocks. Different lower-case letters indicate statistically significant differences based on Duncan's multiple range post-hoc test $(\alpha=0.05)$. In the presence of a significant interaction between drought (D) and species (S), the significance letters are valid across species but only remain valid within species when the interaction $(\mathrm{D} \times \mathrm{S})$ was not significant. Different upper-case letters indicate statistically significant differences between species in the absence of a significant $\mathrm{D} \times \mathrm{S}$ interaction. ${ }^{*} p<0.05$. 

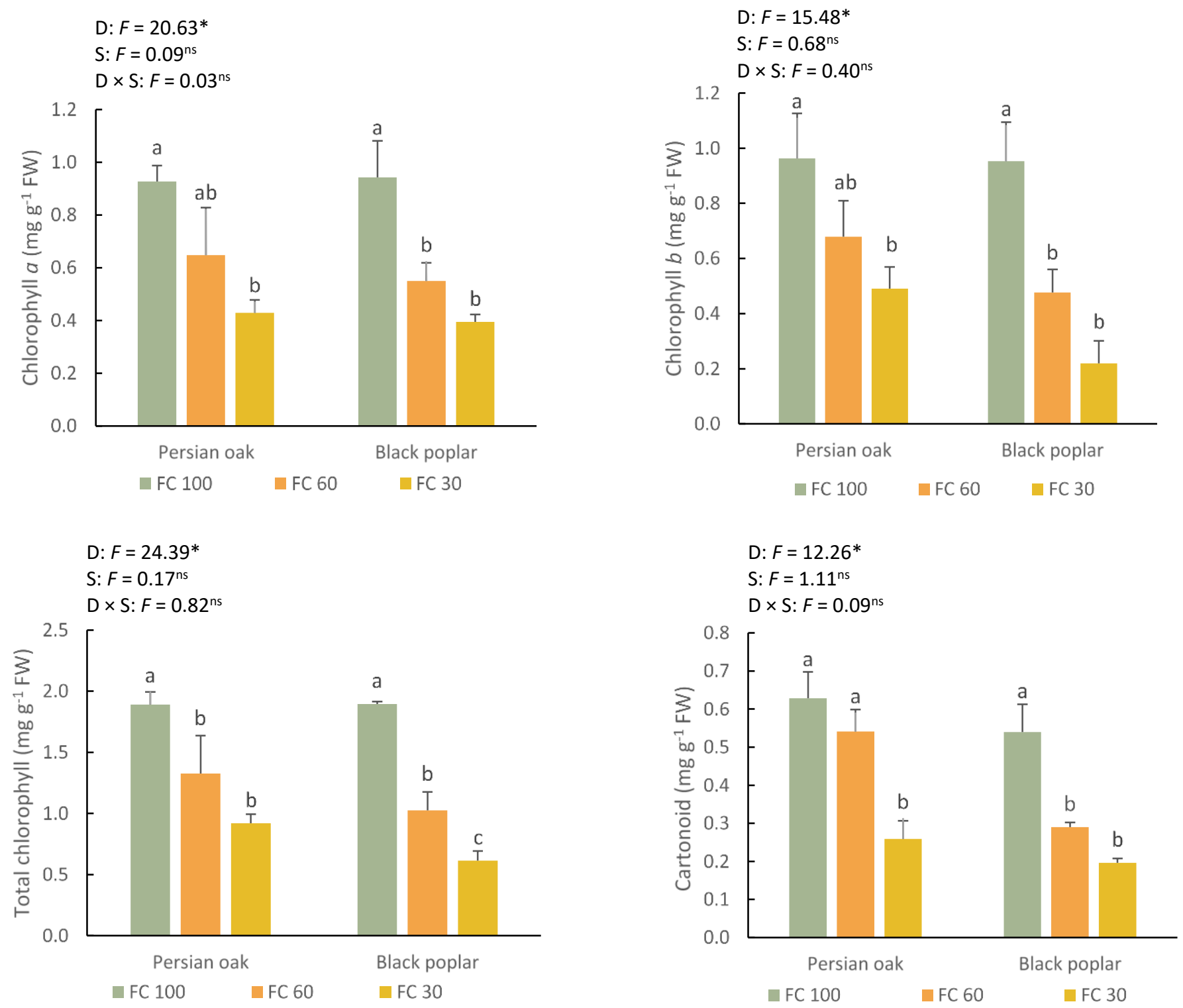

Figure 4. Foliar chlorophyll ( $a, b$, and total) and carotenoid content of Persian oak and black poplar seedlings as a function of soil water deficit. Means \pm standard deviation, $n=3$ blocks. Different lower-case letters indicate statistically significant differences based on Duncan's multiple range post-hoc test $(\alpha=0.05)$. In the presence of a significant interaction between drought (D) and species $(S)$, the significance letters are valid across species but only remain valid within species when the interaction $(\mathrm{D} \times \mathrm{S})$ was not significant. $\mathrm{FW}=$ fresh weight. ${ }^{*} p<0.05$. 

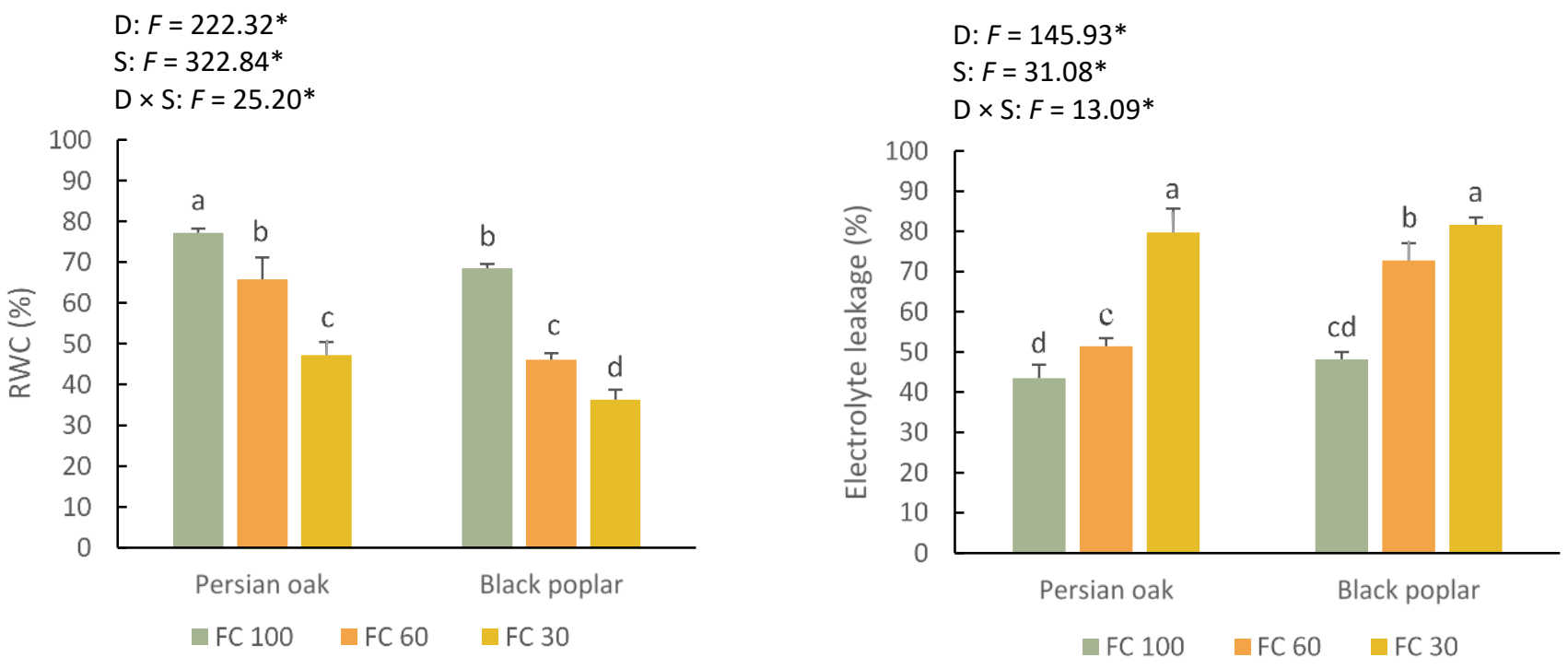

D: $F=108.04^{*}$

S: $F=130.26^{*}$

$\mathrm{D} \times \mathrm{S}: F=33.59^{*}$

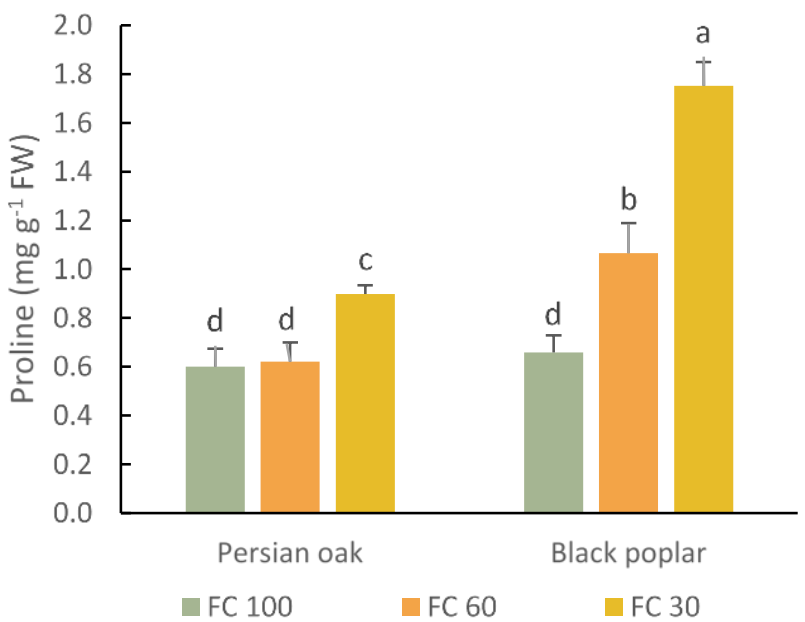

D: $F=49.77^{*}$

S: $F=210.46^{*}$

$D \times S: F=20.59^{*}$

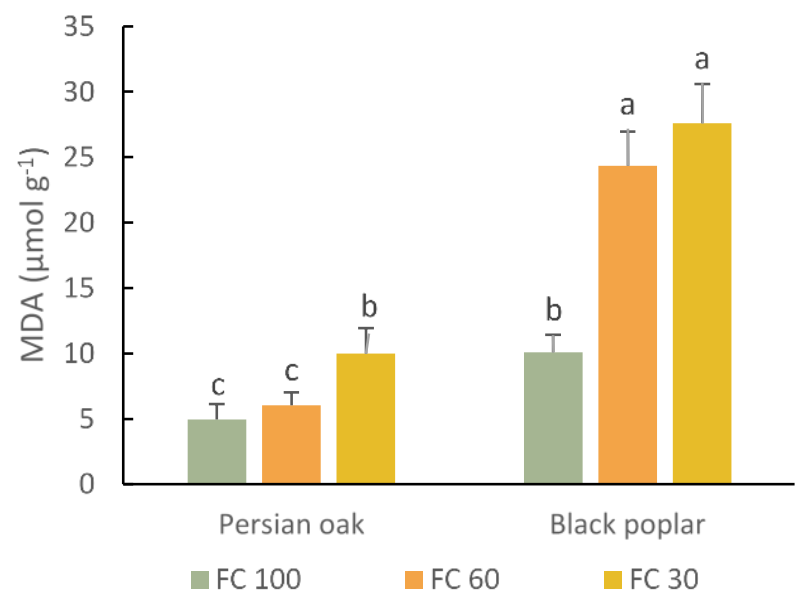

Figure 5. Relative water content (RWC), electrolyte leakage (EL), proline, and malondialdehyde (MDA) content of leaves of Persian oak and black poplar seedlings subjected to three different soil water regimes. Means \pm standard deviation, $n=3$ blocks. Different lower-case letters indicate statistically significant differences based on Duncan's multiple range post-hoc test $(\alpha=0.05)$. In the presence of a significant interaction between drought (D) and species (S), the significance letters are valid across species but only remain valid within species when the interaction $(D \times S)$ was not significant. $\mathrm{FW}=$ fresh weight. ${ }^{*} p<0.05$.

\section{Discussion}

In this study, we investigated drought responses of seedlings of two economically important tree species in the Iranian region to provide decision support to nursery and forest managers.

The ability to survive drought periods and to minimize drought-related growth impairments are integral to drought plant resistance [40]. The high survival rate of Persian oak seedlings even under severe SWD together with the maintenance of height and radial growth under moderate drought stress indicates strong drought resistance. Under slightly more severe SWD (20\% of FC), survival rates of two co-occurring oak species ( $Q$. libani, 
Q. infectoria) were similar to that of Persian oak, while even fewer reductions in height growth ( -22 to $38 \%)$ and diameter growth ( -20 to $30 \%)$ were observed [41]. Black poplar showed greater growth reductions than Persian oak under moderate SWD but under severe SWD both species exhibited similarly large losses. In a comparative study, six black poplar genotypes displayed comparable drought-related declines in height ( $\mathrm{ca}$. -32 to $-88 \%$ ) and diameter growth $(-40$ to $-75 \%$, apart from one genotype responding with increased diameter growth) [42].

Similar to other oak species, the high drought resistance of Persian oak seems to rely largely on drought avoidance through the formation of a well-developed, deep-penetrating root system $[43,44]$. This notion is supported by our root biomass data and the increase in root length under severe SWD, indicating prioritized belowground resource allocation. Drought-induced reductions in the root biomass of oak seedlings did occur but were moderate and of similar magnitude under FC60 and FC30 conditions, leaving root systems with a three times greater biomass compared to those of black poplar seedlings. Although the root biomass of black poplar seedlings remained unaffected by drought, root length declined by more than half under severe SWD in the FC30 treatment, implying an opportunistic rooting strategy geared towards exploiting freshly fallen rain infiltrating the topsoil rather than extending roots to reach deeper-lying soil moisture reservoirs. Under prolonged drought conditions, stomatal downregulation may curtail photosynthetic carbon assimilation, but whether this results in carbon starvation is highly debatable since the cessation of growth processes (sink activity) occurs long before drought-induced reductions in photosynthesis (source activity) limit carbon supply $[45,46]$. Drought-related growth losses are tightly linked to reduced tissue hydration and impaired cell division as well as turgor-driven cell expansion; in short, hydraulic limitations rather than decreases in photosynthetic carbon gain compromise growth under drought conditions [46-48]. The rooting strategy of Persian oak seedlings probably permits access to moister soil horizons and thus allows a favourable leaf water status to be maintained for a longer period under SWD conditions. This is supported by the generally higher RWC in oak seedling foliage, which is essential for proper physiological functioning and thus survival. The strong link between seedling rooting depth and survival under drought conditions has been demonstrated in previous studies based on a range of woody Mediterranean species, including three oak species $[49,50]$. Manes, F. et al. [50] have shown that root responses to drought were not uniform among Mediterranean oak species: for example, the evergreen holm oak (Quercus ilex) maintained root growth during drought but produced thinner roots, resulting in a larger surface/volume ratio and thus promoting water uptake. In deciduous oaks, especially Turkey oak (Q. cerris), root growth and total root length decreased under drought, driven by fine root shedding, but the remaining root system was still exceedingly large in comparison [50]. In our study, we used potted plants to mimic local nursery practices producing container-grown seedling stock. The spatial restrictions to root growth in containers commonly result in root architectures differing vastly from naturally developed root systems, but these initial differences may vanish over time [51]. Compared to bareroot or field-grown plants, container-derived seedlings typically have lower shoot to root ratios and superior root growth potential, conferring greater drought avoidance capacity, which makes them better suited for planting at stress-prone sites [51]. Moreover, container seedlings have been shown to be more resistant to the stresses associated with handling practices (lifting, transport, storage, and planting) and commonly tolerate the transplant shock better than bareroot seedlings [51]. For example, container seedlings of the North American black oak (Quercus velutina Lam.) formed more new roots, resulting in reduced drought stress symptoms and greater survival compared to bareroot seedlings in the first year post-outplanting [52]. Although few studies have reported persisting negative effects of container-induced changes in root system morphology [51], we cannot preclude that those changes may compromise long-term field performance.

Reducing leaf area is the most direct way to lower whole-plant water use and represents a common adaptation to drought in many species [53]. Accordingly, we observed strong 
leaf area reductions in both species similar to prior studies on oak and poplar trees [54-56] and other forestry-relevant species in the same region (e.g., Celtis caucasica L. [57]). Specific leaf area did not vary significantly with increasing SWD, suggesting no major leaf structural changes in adaptation to drought, which is in line with the findings for seedlings of two deciduous and two evergreen oak species from the Mediterranean region [54] and is also consistent with the results of a common garden drought experiment using five black poplar genotypes [42]. However, in a drought-related study comprising numerous Populus deltoides $\times$ Populus nigra genotypes, all of them showed declines in SLA under drought [55].

In our study, Persian oak maintained higher levels of stem growth and biomass under drought than black poplar seedlings, clearly reflected in the Dickson quality index, which integrates above- and belowground growth and biomass variables, allowing performance comparisons among species [34]. The Dickson quality index only showed insignificant drought-related reductions for Persian oak, but scores more than halved under severe SWD in black poplar seedlings and similar deteriorations were reported for drought-exposed seedlings of other regionally important forestry species such as Cupressus sempervirens [58].

Foliar chlorophyll content is tightly correlated with leaf photosynthetic capacity [59]. Drought-driven reductions in leaf chlorophyll and carotenoid content commonly result from chloroplast damage by reactive oxygen species (ROS) and unaltered pigment levels during drought stress thus indicate superior ROS scavenging by antioxidants conferring enhanced drought tolerance [60]. In our experiment, both species showed similar pigment contents and drought-related decreases, apart from the maintenance of carotenoid levels under moderate SWD in Persian oak. The magnitude of the chlorophyll losses in Persian oak makes less oxidative stress than in black poplar an unlikely explanation for the sustained carotenoid levels. Apart from their function in photosynthetic light harvesting, carotenoids also play an important role in oxidative quenching [61] and our finding may thus reflect an upregulation in carotenoid synthesis in support of the oxidative stress defence under moderate SWD in Persian oak. Overall, our pigment findings are in line with those of a previous study on Persian oak testing the interaction between drought and pathogen attack [62] and agree well with the drought-driven pigment losses in the co-occurring Q. infectoria and Q. libani [41]. Chlorophyll and carotenoid losses in response to drought have also been reported for various Populus species, but no chlorophyll changes and even transient increases in carotenoid levels were seen in a drought-adapted ecotype of Manchurian poplar ( $P$. cathayana) while chlorophyll reductions and smaller carotenoid increases occurred in the wet climate ecotype, indicating a strong drought adaptation potential in this poplar species $[23,63]$.

Drought stress promotes the formation of ROS, which play an important role in stress signalling pathways and drought adaptation at low concentrations but cause oxidative damage at higher levels. Stress-driven increases in ROS often result in elevated membrane lipid damage associated with increased leakage of electrolytes [64]. In our study, EL increased with increasing drought intensity in both species, reaching similar levels under severe SWD. However, while EL in black poplar had already increased by more than $50 \%$ under moderate SWD (FC60), Persian oak seedlings showed only minor increases in EL, indicating less oxidative membrane damage, possibly linked to the relatively high carotenoid content and their antioxidant activity.

Drought-related increases in EL of varying magnitude have been reported for various Populus species $[23,65]$ and other forestry and horticulturally important woody species in the study region such as wild pear (Pyrus biossieriana Buhse) [66] and common myrtle (Myrtus communis) [18]. The strong increase in EL (+84\%) seen in Persian oak under FC30 conditions is consistent with the doubling of EL observed in the co-occurring Q. libani under severe SWD ( $20 \%$ of FC), while $Q$. infectoria, protected by a superior antioxidant defence, displayed substantially lower EL at this level of SWD [41].

Plants have evolved defence systems based on antioxidants and secondary metabolites that are geared towards detoxifying ROS, stabilizing proteins/enzymes, and reducing membrane damage, so that this line of defence forms a critical component of the abiotic 
stress resistance [67]. The multifunctional amino acid proline plays a vital role in the plant stress response as an osmoregulant, antioxidant, and signalling molecule $[68,69]$. Therefore, proline synthesis is often upregulated in response to environmental stress $[24,69,70]$. This is frequently accompanied by increases in non-structural carbohydrates (NSC) which may alleviate negative drought symptoms due to their osmoregulatory role [71]. However, the ability of Persian oak seedlings to maintain adequate RWC during moderate drought may obviate or reduce the need for large proline pools, though we cannot rule out increases in other osmoregulants, such as NSC, since drought-induced osmotic adjustment has been reported for a range of coniferous and broadleaf trees, including other oak species [44,72,73]. Persian oak co-occurs with two other oaks species, of which $Q$. infectoria showed a similar rise in proline but in response to strong SWD (20\% of FC), while proline levels of $Q$. libani remained unchanged [70]. Under severe SWD, proline levels in Persian oak seedling foliage rose significantly in our study but to a much lesser extent compared to black poplar seedlings. The rapid decline in RWC of drought-exposed black poplar seedlings down to values below 50\% (already under moderate SWD) entailed a strong increase in proline promoting enhanced osmotic adjustment to halt the deterioration of leaf water status. This is consistent with previous findings of strong osmotic adjustment in drought-treated cuttings of black poplar clones, which strongly relied on the conversion of root starch reserves to non-structural carbohydrates [74]. In the same study, reduced resource (carbon) allocation to roots was found and, depending on clone identity, either no change or a reduction in root biomass occurred, but certainly no sign of an increased investment in a larger or deeper-penetrating root system, which is in line with our findings [74]. However, a comparative study has shown that drought responses may vary widely among black poplar clones with large differences in drought-related growth reductions, proline build-up, and oxidative damage indicated by MDA accumulation [75]. Malondialdehyde is a major breakdown product of membrane lipid peroxidation caused by reactive oxygen species and thus a strong oxidative stress marker that may surge under stress conditions [76]. In our study, MDA accumulated much more strongly in black poplar than in Persian oak seedlings, indicating greater oxidative damage and hence a greater susceptibility to drought. Similarly strong increases in MDA were reported for three Populus hybrids exposed to the same level of severe SWD (30\% of FC) as in our study [19]. However, a previous investigation on drought responses of Persian oak seedlings originating from different regions in the Zagros Mountains in Iran found strong variation in MDA levels, indicating varying severity of oxidative membrane damage [11]. The two main oak species (Q. infectoria, $Q$. libani) co-occurring with Persian oak in Iran's Zagros Mountains also showed much stronger MDA accumulation under severe drought, implying greater oxidative stress than in Persian oak [70].

\section{Conclusions}

Regional climate projections predict more frequent and severe water shortages, implying that rooting depth will become an ever more decisive trait for promoting seedling establishment and safeguarding reforestation and afforestation efforts. Selecting droughtresistant tree species is critical to plantation establishment success and this first comparison of two locally important timber species therefore makes an important contribution to forestry decision-making in the Zagros region. The majority of the morpho-physiological (especially survival) and biochemical variables assessed in our study indicate superior drought resistance of Persian oak compared to black poplar (at least under moderate drought conditions). There is certainly large genotypic variation in drought-related traits of black poplar, but the development of a deep-rooting habit has never emerged as an adaptation to drought. Increases in root length of Persian oak seedlings growing under soil water deficit indicate root system plasticity to drought which allows tapping into deeper soil water reserves, thereby mitigating negative drought effects. Our findings are highly relevant for forest practitioners and stakeholders as adaptive forest management strategies will be guided by measures aimed at preventing or minimizing drought-related 
risks and yield losses. This starts with sustainable nursery seedling production, and in water-scarce areas the unfavourable economics of irrigation or its sheer impracticability make water-demanding species such as black poplar an improvident choice for the future. Propagating Persian oak in nurseries will certainly be simpler, more cost-effective, and less risky in a drier future and the resulting seedling stock is likely to have high establishment success rates in the field. However, changes in root system morphology associated with the prevailing container propagation in nurseries may affect long-term seedling performance in the field and thus motivates follow-up research on plant health status and stand development for an extended period after outplanting.

Author Contributions: Conceptualization, A.K. and M.T.; methodology, A.K. and M.T.; software, A.K.; validation, M.T. and M.K.-F.B.; formal analysis, A.K.; investigation, A.K.; resources, Z.J.; data curation, A.K.; writing-original draft preparation, A.K.; writing-review and editing, M.T. and M.K.-F.B.; visualization, A.K. and M.K.-F.B.; supervision, M.T.; project administration, M.T.; funding acquisition, M.T. All authors have read and agreed to the published version of the manuscript.

Funding: This research was funded by Tarbiat Mordares University.

Data Availability Statement: Data is available upon request from the corresponding authors.

Conflicts of Interest: The authors declare no conflict of interest.

\section{References}

1. Fenner, M. Seedlings. New Phytol. 1987, 106, 35-47. [CrossRef]

2. Allen, C.D.; Breshears, D.D.; McDowell, N.G. On Underestimation of Global Vulnerability to Tree Mortality and Forest Die-off from Hotter Drought in the Anthropocene. Ecosphere 2015, 6, 1-55. [CrossRef]

3. Ovalle, J.F.; Arellano, E.C.; Ginocchio, R.; Editors, A.; Altaf Arain, M.; Jokela, E.J. Trade-Offs between Drought Survival and Rooting Strategy of Two South American Mediterranean Tree Species: Implications for Dryland Forests Restoration. Forests 2015, 6, 3733-3747. [CrossRef]

4. López, B.C.; Holmgren, M.; Sabaté, S.; Gracia, C.A. Estimating Annual Rainfall Threshold for Establishment of Tree Species in Water-Limited Ecosystems Using Tree-Ring Data. J. Arid Environ. 2008, 72, 602-611. [CrossRef]

5. Farooq, M.; Wahid, A.; Kobayashi, N.; Fujita, D.; Basra, S.M.A. Plant Drought Stress: Effects, Mechanisms and Management. Sustain. Agric. 2009, 29, 153-188. [CrossRef]

6. Aspelmeier, S.; Leuschner, C. Genotypic Variation in Drought Response of Silver Birch (Betula pendula Roth): Leaf and Root Morphology and Carbon Partitioning. Trees-Struct. Funct. 2006, 20, 42-52. [CrossRef]

7. Ruthrof, K.X.; Bader, M.K.F.; Matusick, G.; Jakob, S.; Hardy, G.E.S.J. Promoting Seedling Physiological Performance and Early Establishment in Degraded Mediterranean-Type Ecosystems. New For. 2016, 47, 357-376. [CrossRef]

8. Bader, M.K.F.; Ehrenberger, W.; Bitter, R.; Stevens, J.; Miller, B.P.; Chopard, J.; Rüger, S.; Hardy, G.E.S.J.; Poot, P.; Dixon, K.W.; et al. Spatio-Temporal Water Dynamics in Mature Banksia menziesii Trees during Drought. Physiol. Plant. 2014, 152, 301-315. [CrossRef]

9. Oraee, A.; Tehranifar, A. Evaluating the Potential Drought Tolerance of Pansy through Its Physiological and Biochemical Responses to Drought and Recovery Periods. Sci. Hortic. 2020, 265, 109225. [CrossRef]

10. Zahedi, S.M.; Rasoli, F.; Gohari, G. The Effect of Potassium on the Yield and Concentrations of Microelements in Cowpea (Vigna unguiculata L. Walp.) under Drought Stress. J. Iran. Plant Ecophysiol. Res. 2018, 12, 25-34.

11. Jafarnia, S.; Akbarinia, M.; Hosseinpour, B.; Modarres Sanavi, S.A.; Salami, S.A. Effect of Drought Stress on Some Growth, Morphological, Physiological, and Biochemical Parameters of Two Different Populations of Quercus brantii. iForest 2018, 11, 212-220. [CrossRef]

12. Aalipour, H.; Nikbakht, A.; Etemadi, N.; Rejali, F.; Soleimani, M. Biochemical Response and Interactions between Arbuscular Mycorrhizal Fungi and Plant Growth Promoting Rhizobacteria during Establishment and Stimulating Growth of Arizona Cypress (Cupressus arizonica G.) under Drought Stress. Sci. Hortic. 2020, 261, 108923. [CrossRef]

13. Li, Z.; Wu, N.; Liu, T.; Chen, H.; Tang, M. Correction: Sex-Related Responses of Populus cathayana Shoots and Roots to AM Fungi and Drought Stress. PLoS ONE 2015, 10, e0128841. [CrossRef]

14. Kumari, A.; Singh, A.K.; Singh, S.K.; Khan, I.M. Morphological, Physiological and Biochemical Responses of Poplar Plants to Drought Stress. J. AgriSearch 2018, 5, 184-189. [CrossRef]

15. Echevarría-Zomeño, S.; Ariza, D.; Jorge, I.; Lenz, C.; del Campo, A.; Jorrín, J.v.; Navarro, R.M. Changes in the Protein Profile of Quercus ilex Leaves in Response to Drought Stress and Recovery. J. Plant Physiol. 2009, 166, 233-245. [CrossRef]

16. Ashkavand, P.; Tabari Koucheksraei, M.; Zarafshar, M.; Ghanbary, E. Morpho-Physiological Change of Mahaleb Cherry (Prunus mahaleb L.) Seedlings under Silicon Nanoparticles ( $\left.\mathrm{SiO}_{2} \mathrm{NPs}\right)$ Affected. Appl. Biol. 2017, 29, 45-58. [CrossRef]

17. Ghasemi, M.; Arzani, K.; Yadollahi, A.; Hokmabadi, H.; Ghasemi, S. Effect of Drought Stress on Abscisic Acid Changes, Leaf Water Potential and Relative Water Content of Some Pistachio Seedling Rootstocks. J. Pist. Sci. Technol. 2020, 4, 120-131. 
18. Azizi, S.; Tabari, K.M.; Hadian, J.; Fallah, N.A.A.; Modarres, S.S.A.M. Physiological Responses of Common Myrtle Seedling (Myrtus communis L.) to Multimicrobial Inoculation under Water Deficit Stress. J. Sol. Biol. 2019, 7, 167-180.

19. Bhusal, N.; Lee, M.; Reum Han, A.; Han, A.; Kim, H.S. Responses to Drought Stress in Prunus sargentii and Larix kaempferi Seedlings Using Morphological and Physiological Parameters. For. Ecol. Manag. 2020, 465, 118099. [CrossRef]

20. Sisakht Nejad, M.; Zolfaghari, R. The Effect of Water Stress on Gas Exchange in Two Iranian Oak Species (Quercus brantii) and Vyvl (Quercus libani). Zagros For. Res. 2015, 1, 15-31.

21. Sadeghzadeh Hallaj, M.H.; Azadfar, D.; Mirzaei Nodoushan, H.; Arzanesh, M.H.; Tohidfar, M. Shade Role in Facilitation Drought Stress Symptoms on Physiology of Mount Atlas Mastic (Pistacia atlantica Desf.) Seedlings. Iran. J. For. Poplar Res. 2017, 25, 332-341. [CrossRef]

22. Tafreshi, S.A.; Aghaie, P.; Momayez, H.R.; Hejaziyan, S.A. Response of in Vitro-Regenerated Myrtus communis L. Shoots to PEG-Induced Water Stress. Biocatal. Agric. Biotechnol. 2021, 34, 102033. [CrossRef]

23. Yi, L.; Li, B.; Korpelainen, H.; Yu, F.; Wu, L.; Tong, L.; Liu, M. Mechanisms of Drought Response in Populus. South For. 2020, 82, 359-366. [CrossRef]

24. Azizi, S.; Tabari Kouchaksaraei, M.; Hadian, J.; Fallah Nosrat Abad, A.R.; Modarres Sanavi, S.A.M.; Ammer, C.; Bader, M.K.F. Dual Inoculations of Arbuscular Mycorrhizal Fungi and Plant Growth-Promoting Rhizobacteria Boost Drought Resistance and Essential Oil Yield of Common Myrtle. For. Ecol. Manag. 2021, 497, 119478. [CrossRef]

25. Aaltonen, H.; Linden, A.; Heinonsalo, J.; Biasi, C.; Pumpanen, J. Effects of Prolonged Drought Stress on Scots Pine Seedling Carbon Allocation. Tree Physiol. 2017, 37, 418-427. [CrossRef]

26. Jazirehi, M.; Rostaghi, M.E. Zagros Silviculture; University of Tehran Publications: Tehran, Iran, 2003; Volume 264, pp. 560-561.

27. Wei, H.; Movahedi, A.; Xu, C.; Sun, W.; Li, L.; Wang, P.; Li, D.; Zhuge, Q. Overexpression of PtHMGR Enhances Drought and Salt Tolerance of Poplar. Ann. Bot. 2020, 125, 785-803. [CrossRef]

28. Tschaplinski, T.J.; Tuskan, G.A.; Gunderson, C.A. Water-Stress Tolerance of Black and Eastern Cottonwood Clones and Four Hybrid Progeny. I. Growth, Water Relations, and Gas Exchange. Can. J. For. Res. 1994, 24, 364-371. [CrossRef]

29. Bayatkashkoli, A.; Amiri, S.; Soltani, A.; Faezipour, M.; Doosthoseini, K. Assessment of Internal Trade of Iranian Poplar Timber. Iran. J. Nat. Resour. 2009, 1, 1397-1415.

30. Hosseini, S.S.; Shahnabati, N.; Salami, H.; Yazdani, S.; Calagari, M. Estimating the Demand for Poplar Wood in the Wood and Paper Industries of Iran. Iran. J. For. Poplar Res. 2021, 29, 65-76. [CrossRef]

31. Vaghefi, S.A.; Keykhai, M.; Jahanbakhshi, F.; Sheikholeslami, J.; Ahmadi, A.; Yang, H.; Abbaspour, K.C. The Future of Extreme Climate in Iran. Sci. Rep. 2019, 9, 1464. [CrossRef]

32. Zarik, L.; Meddich, A.; Hijri, M.; Hafidi, M.; Ouhammou, A.; Ouahmane, L.; Duponnois, R.; Boumezzough, A. Use of Arbuscular Mycorrhizal Fungi to Improve the Drought Tolerance of Cupressus atlantica G. C. R. Biol. 2016, 339, 185-196. [CrossRef] [PubMed]

33. Marshall, J.D.; Monserud, R.A. Foliage Height Influences Specific Leaf Area of Three Conifer Species. Can. J. For. Res. 2003, 33, 164-170. [CrossRef]

34. Dickson, A.; Leaf, A.L.; Hosner, J.F. Quality Appraisal of White Spruce and White Pine Seedling Stock in Nurseries. For. Chron. 1960, 36, 10-13. [CrossRef]

35. Guo, J.; Yang, Y.; Wang, G.; Yang, L.; Sun, X. Ecophysiological Responses of Abies fabri Seedlings to Drought Stress and Nitrogen Supply. Physiol. Plant. 2010, 139, 335-347. [CrossRef]

36. Campos, P.S.; Quartin, V.; Ramalho, J.C.; Nunes, M.A. Electrolyte Leakage and Lipid Degradation Account for Cold Sensitivity in Leaves of Coffea sp. Plants. J. Plant Physiol. 2003, 160, 283-292. [CrossRef]

37. Arnon, D.I. Copper Enzymes in Isolated Chloroplasts. Polyphenoloxidase in Beta vulgaris. Plant Physiol. 1949, 24, 1-15. [CrossRef]

38. Heath, R.L.; Packer, L. Photoperoxidation in Isolated Chloroplasts. I. Kinetics and Stoichiometry of Fatty Acid Peroxidation. Arch. Biochem. Biophys. 1968, 125, 189-198. [CrossRef]

39. Bates, L.S.; Waldren, R.P.; Teare, I.D. Rapid Determination of Free Proline for Water-Stress Studies. Plant Soil 1973, 39, 205-207. [CrossRef]

40. Engelbrecht, B.M.J.; Kursar, T.A. Comparative Drought-Resistance of Seedlings of 28 Species of Co-Occurring Tropical Woody Plants. Oecologia 2003, 136, 383-393. [CrossRef]

41. Ghanbary, E.; Fathizadeh, O.; Pazhouhan, I.; Zarafshar, M.; Kouchaksaraei, M.T.; Jafarnia, S.; Parad, G.A.; Bader, M.K.F. Drought and Pathogen Effects on Survival, Leaf Physiology, Oxidative Damage, and Defense in Two Middle Eastern Oak Species. Forests 2021, 12, 247. [CrossRef]

42. Viger, M.; Smith, H.K.; Cohen, D.; Dewoody, J.; Trewin, H.; Steenackers, M.; Bastien, C.; Taylor, G. Adaptive Mechanisms and Genomic Plasticity for Drought Tolerance Identified in European Black Poplar (Populus nigra L.). Tree Physiol. 2016, 36, 909-928. [CrossRef] [PubMed]

43. Abrams, M.D. Adaptations and Responses to Drought in Quercus Species of North America. Tree Physiol. 1990, 7, $227-238$. [CrossRef]

44. Thomas, F.M.; Gausling, T.; For Sci, A.; Thomas, F.; Gausling, T. Morphological and Physiological Responses of Oak Seedlings (Quercus petraea and Q. robur) to Moderate Drought. Ann. For. Sci. 2000, 57, 325-333. [CrossRef]

45. Muller, B.; Pantin, F.; Génard, M.; Turc, O.; Freixes, S.; Piques, M.; Gibon, Y. Water Deficits Uncouple Growth from Photosynthesis, Increase C Content, and Modify the Relationships between C and Growth in Sink Organs. J. Exp. Bot. 2011, 62, 1715-1729. [CrossRef] [PubMed] 
46. Körner, C. Paradigm Shift in Plant Growth Control. Curr. Opin. Plant Biol. 2015, 25, 107-114. [CrossRef]

47. Tardieu, F. Plant Response to Environmental Conditions: Assessing Potential Production, Water Demand, and Negative Effects of Water Deficit. Front. Physiol. 2013, 4, 17. [CrossRef] [PubMed]

48. Choat, B.; Jansen, S.; Brodribb, T.J.; Cochard, H.; Delzon, S.; Bhaskar, R.; Bucci, S.J.; Feild, T.S.; Gleason, S.M.; Hacke, U.G.; et al. Global Convergence in the Vulnerability of Forests to Drought. Nature 2012, 491, 752-755. [CrossRef]

49. Padilla, F.M.; Pugnaire, F.I. Rooting Depth and Soil Moisture Control Mediterranean Woody Seedling Survival during Drought. Funct. Ecol. 2007, 21, 489-495. [CrossRef]

50. Manes, F.; Vitale, M.; Donato, E.; Giannini, M.; Puppi, G. Different Ability of Three Mediterranean Oak Species to Tolerate Progressive Water Stress. Photosynthetica 2006, 44, 387-393. [CrossRef]

51. Grossnickle, S.C.; El-Kassaby, Y.A. Bareroot versus Container Stocktypes: A Performance Comparison. New For. 2016, 47, 1-51. [CrossRef]

52. Dixon, R.K.; Pallardy, S.G.; Garrett, H.E.; Cox, G.S.; Sander, I.L. Comparative Water Relations of Container-Grown and Bare-Root Ectomycorrhizal and Nonmycorrhizal Quercus velutina Seedlings. Can. J. Bot. 1983, 61, 1559-1565. [CrossRef]

53. Larcher, W. Physiological Plant Ecology; Springer: Berlin/Heidelberg, Germany, 2003.

54. Luis Quero, J.; Villar, R.; Marañón, T.; Zamora, R.; Quero, J.L. Interactions of Drought and Shade Effects on Seedlings of Four Quercus Species: Physiological and Structural Leaf Responses. New Phytol. 2006, 170, 819-834. [CrossRef] [PubMed]

55. Monclus, R.; Dreyer, E.; Villar, M.; Delmotte, F.M.; Delay, D.; Petit, J.-M.; Barbaroux, C.; le Thiec, D.; Bréchet, C.; Brignolas, F. Impact of Drought on Productivity and Water Use Efficiency in 29 Genotypes of Populus deltoides $\times$ Populus nigra. New Phytol. 2006, 169, 765-777. [CrossRef]

56. Zhao, C.; Si, J.; Feng, Q.; Yu, T.; Luo, H.; Qin, J.; Sepahvand, T.; Etemad, V.; Matinizadeh, M.; Shirvany, A. Ecophysiological Responses to Drought Stress in Populus euphratica. Sci. Cold Arid Reg. 2021, 13, 326-336. [CrossRef]

57. Sepahvand, T.; Etemad, V.; Matinizadeh, M.; Shirvany, A. Symbiosis of AMF with Growth Modulation and Antioxidant Capacity of Caucasian Hackberry (Celtis caucasica L.) Seedlings under Drought Stress. Cent. Asian J. Environ. Sci. Technol. Innov. 2021, 1 , 20-35.

58. Rooki, M.; Tabari Kouchaksaraei, M.; Ehsan, S. The Role of Rhizobacteria Pseudomonas Fluorescens in Improving Morphological Traits of Cupressus sempervirens Var. Horizontalis Seedling under Water Deficit. J. For. Wood Prod. 2019, 72, 205-213. [CrossRef]

59. Croft, H.; Chen, J.M.; Luo, X.; Bartlett, P.; Chen, B.; Staebler, R.M. Leaf Chlorophyll Content as a Proxy for Leaf Photosynthetic Capacity. Glob. Chang. Biol. 2017, 23, 3513-3524. [CrossRef]

60. Tatari, M.; Jafari, A.; Shirmardi, M.; Mohamadi, M. Using Morphological and Physiological Traits to Evaluate Drought Tolerance of Pear Populations (Pyrus spp.). Int. J. Fruit Sci. 2020, 20, 837-854. [CrossRef]

61. Ramel, F.; Birtic, S.; Cuiné, S.; Triantaphylidès, C.; Ravanat, J.L.; Havaux, M. Chemical Quenching of Singlet Oxygen by Carotenoids in Plants. Plant Physiol. 2012, 158, 1267. [CrossRef]

62. Ghanbary, E.; Kouchaksaraei, M.T.; Guidi, L.; Mirabolfathy, M.; Etemad, V.; Sanavi, S.A.; Struve, D. Change in Biochemical Parameters of Persian Oak (Quercus brantii Lindl.) Seedlings Inoculated by Pathogens of Charcoal Disease under Water Deficit Conditions. Trees 2018, 32, 1595-1608. [CrossRef]

63. Xiao, X.; Xu, X.; Xiao, F.Y.; Xu, X.; Yang, X. Adaptive Responses to Progressive Drought Stress in Two Populus cathayana Populations Silva Fenn. 2008, 42, 705-719. [CrossRef]

64. Gill, S.S.; Tuteja, N. Reactive Oxygen Species and Antioxidant Machinery in Abiotic Stress Tolerance in Crop Plants. Plant Physiol. Biochem. 2010, 48, 909-930. [CrossRef] [PubMed]

65. Xiao, X.; Yang, F.; Zhang, S.; Korpelainen, H.; Li, C. Physiological and Proteomic Responses of Two Contrasting Populus cathayana Populations to Drought Stress. Physiol. Plant. 2009, 136, 150-168. [CrossRef]

66. Karimi, M.; KIAN, E.F.; Zahedi, S.M.; Karimi, K.A. Determination of the Most Important Traits Affecting the Electrolyte Leakage of Wild Pear (Pyrus biossieriana Buhse) under Drought Stress Conditions Using Multivariate Statistical Methods. J. Plant Environ. Physiol. 2018, 13, 83-94.

67. Seki, M.; Umezawa, T.; Urano, K.; Shinozaki, K. Regulatory Metabolic Networks in Drought Stress Responses. Curr. Opin. Plant Biol. 2007, 10, 296-302. [CrossRef] [PubMed]

68. Hayat, S.; Hayat, Q.; Alyemeni, M.N.; Wani, A.S.; Pichtel, J.; Ahmad, A. Role of Proline under Changing Environments: A Review. Plant Signal. Behav. 2012, 7, 1456-1466. [CrossRef] [PubMed]

69. Jaleel, C.A.; Manivannan, P.; Sankar, B.; Kishorekumar, A.; Gopi, R.; Somasundaram, R.; Panneerselvam, R. Induction of Drought Stress Tolerance by Ketoconazole in Catharanthus roseus Is Mediated by Enhanced Antioxidant Potentials and Secondary Metabolite Accumulation. Colloids Surf. B Biointerfaces 2007, 60, 201-206. [CrossRef]

70. Ghanbary, E.; Tabari Kouchaksaraei, M.; Zarafshar, M.; Bader, K.F.M.; Mirabolfathy, M.; Ziaei, M. Differential Physiological and Biochemical Responses of Quercus infectoria and Q. libani to Drought and Charcoal Disease. Physiol. Plant. 2020, 168, 876-892. [CrossRef]

71. O'Brien, M.J.; Leuzinger, S.; Philipson, C.D.; Tay, J.; Hector, A. Drought Survival of Tropical Tree Seedlings Enhanced by Non-Structural Carbohydrate Levels. Nat. Clim. 2014, 4, 710-714. [CrossRef]

72. Bhusal, N.; Lee, M.; Lee, H.; Adhikari, A.; Han, A.R.; Han, A.; Kim, H.S. Evaluation of Morphological, Physiological, and Biochemical Traits for Assessing Drought Resistance in Eleven Tree Species. Sci. Total Environ. 2021, 779, 146466. [CrossRef] 
73. Khaleghi, A.; Naderi, R.; Brunetti, C.; Maserti, B.E.; Salami, S.A.; Babalar, M. Morphological, Physiochemical and Antioxidant Responses of Maclura pomifera to Drought Stress. Sci. Rep. 2019, 9, 1-12. [CrossRef] [PubMed]

74. Regier, N.; Streb, S.; Cocozza, C.; Schaub, M.; Cherubini, P.; Zeeman, S.C.; Frey, B. Drought Tolerance of Two Black Poplar (Populus nigra L.) Clones: Contribution of Carbohydrates and Oxidative Stress Defence. Plant Cell Environ. 2009, 32, 1724-1736. [CrossRef] [PubMed]

75. Bojović, M.M.; Borišev, M.; Župunski, M. Clonal Differences of Black Poplar Cuttings for Morpho-Physiological and Biochemical Responses to Soil Water Deficits. Artic. J. Anim. Plant Sci. 2013, 23, 1725-1732.

76. Morales, M.; Munné-Bosch, S. Malondialdehyde: Facts and Artifacts. Plant Physiol. 2019, 180, 1246. [CrossRef] [PubMed] 